\title{
Tualang Honey Ameliorates Hypoxia-induced Memory Deficits by Reducing Neuronal Damage in the Hippocampus of Adult Male Sprague Dawley Rats
}

\author{
Tualang Balı, Yetişkin Erkek Sprague Dawley Sıçanlarının \\ Hipokampusundaki Nöronal Hasarı Azaltarak Hipoksiye Bağlı Bellek \\ Kayıplarını İyileştiriyor
} \author{
(D) Zahiruddin OTHMAN4 , (D) Asma Hayati AHMAD1, (D) Che Badariah ABD AZIZ1', (D Sangu MUTHURAJU5 \\ 1 Universiti Sains Malaysia, School of Medical Sciences, Department of Physiology, Kubang Kerian, Malaysia \\ 2Universiti Sains Malaysia, School of Medical Sciences, Department of Anatomy, Kubang Kerian, Malaysia \\ 3 Universiti Sains Malaysia, School of Biological Sciences, Penang, Malaysia \\ 4 Universiti Sains Malaysia, School of Medical Sciences, Department of Psychiatry, Kubang Kerian, Malaysia \\ 5 Universiti Sains Malaysia, School of Medical Sciences, Department of Neuroscience, Kubang Kerian, Malaysia
}

(D) Entesar Yaseen Abdo QAID1, (D) Rahimah ZAKARIA1*, (D) Nurul Aiman MOHD YUSOF2, (D) Shaida Fariza SULAIMAN33, (D) Nazlahshaniza SHAFIN1,

\begin{abstract}
Objectives: A growing body of evidence indicates that hypoxia exposure causes learning and memory deficits. An effective natural therapeutic approach has, however, not been explored widely. Our previous studies found that Tualang honey administration protected learning and memory functions in ovariectomized rats. Therefore, the present study investigated its efficacy in ameliorating hypoxia-induced memory deficits in adult male Sprague Dawley rats.

Materials and Methods: The rats were divided into four groups: i) Normoxia treated with sucrose $(n=12)$, ii) Normoxia treated with Tualang honey $(\mathrm{n}=12)$, iii) Hypoxia treated with sucrose $(\mathrm{n}=12)$, and iv) Hypoxia treated with Tualang honey $(\mathrm{n}=12)$. Tualang honey $(0.2 \mathrm{~g} / \mathrm{kg} / \mathrm{BW})$ and sucrose $(1$ $\mathrm{mL}$ of $7.9 \%$ ) supplementations were administered orally to the rats daily for 14 days. Then the hypoxia groups were exposed to hypoxia ( $11 \%$ ) for 7 days, while the normoxia groups were kept in normal conditions. Following exposure to hypoxia, the rats' memories were analyzed using a novel object recognition task and T-maze test.

Results: The data revealed that rats exposed to hypoxia showed significant impairment in short-term memory (STM), spatial memory ( $\mathrm{p}<0.01$ ), and long-term memory (LTM) when compared to the normoxia group. Hypoxia rats treated with Tualang honey showed significant improvement in STM, LTM, and spatial memory ( $p<0.05)$ compared with those treated with sucrose $(p<0.05)$. Tualang honey also reduced neuronal damage in the hippocampus of adult male Sprague Dawley rats exposed to hypoxia.

Conclusion: It is suggested that Tualang honey pretreatment has protective effects against hypoxia-induced memory deficits, possibly through its antioxidant contents.
\end{abstract}

Key words: Hypoxia, Tualang honey, sucrose, memory performance, novel object recognition task, T-maze

Öz

Amaç: Giderek artan sayıda kanıt, hipoksiye maruz kalmanın öğrenme ve hafıza eksikliklerine neden olduğunu göstermektedir. Bununla birlikte, etkili doğal kaynaklı terapötik yaklaşım detaylı araştırılmamıştır. Önceki çalışmalarımız, Tualang bal uygulamasının ovarektomi yapılmış sıçanlarda öğrenme ve hafıza işlevlerini koruduğunu bulmuştur. Bu nedenle, bu çalışmada Tualang balının yetişkin erkek Sprague Dawley sıçanlarında hipoksinin neden olduğu hafıza kayıplarını gidermedeki etkinliği araştırıldı.

*Correspondence: E-mail: rahimah@usm.my, Phone: +6097676156 ORCID-ID: orcid.org/0000-0002-2459-3213

Received: 16.10.2018, Accepted: 07.03.2019

-Turk J Pharm Sci, Published by Galenos Publishing House. 
Gereç ve Yöntemler: Sıçanlar dört gruba ayrıldı: i) sükroz ile muamele edilmiş Normoksi (n=12), ii) Tualang balı ile muamele edilmiş normoksi $(n=12)$, iii) sükroz ile muamele edilmiş hipoksi ( $n=12)$ ve iv) Tualang balı ile tedavi edilen hipoksi $(n=12)$. Tualang balı $(0,2 \mathrm{~g} / \mathrm{kg} / \mathrm{BW})$ ve sükroz $(1 \mathrm{~mL} \% 7,9)$ takviyeleri 14 gün boyunca her gün farelere ağızdan uygulandı. Daha sonra hipoksi grupları 7 gün süreyle hipoksiye ( \%11) maruz bırakılırken, normoksi grupları normal koşullarda tutuldu. Hipoksiye maruz kalmanın ardından, farelerin bellek analizleri yeni bir nesne tanıma görevi ve T-labirent testi kullanılarak yapıldı.

Bulgular: Veriler, hipoksiye maruz kalan sıçanların normoksi grubuna kıyasla kısa süreli belleğinde (STM), uzamsal belleğinde ( $p<0,01)$ ve uzun süreli belleğinde (LTM) anlamlı kayıp olduğunu ortaya koydu. Tualang balı ile tedavi edilen hipoksi sıçanları, sükroz ile tedavi edilenlere kıyasla $(p<0,05)$ STM, LTM ve uzamsal hafızada önemli gelişme gösterdi $(p<0,05)$. Tualang balı, hipoksiye maruz kalan yetişkin erkek Sprague Dawley sıçanlarının hipokampusundaki nöronal hasarı da azalttı.

Sonuç: Tualang balı ön tedavisinin, muhtemelen antioksidan içeriği yoluyla, hipoksiye bağlı hafıza kayıplarına karşı koruyucu etkilere sahip olduğu ileri sürülmektedir.

Anahtar kelimeler: Hipoksi, Tualang balı, sükroz, bellek performansı, yeni nesne tanıma görevi, T-labirenti

\section{INTRODUCTION}

High altitude is considered one of the most adverse environments, where hypoxia causes many physiological and psychological changes in humans as well as in animals., ${ }^{1,2}$ The challenge to regulate homeostasis of oxygen at high altitude is important for the survival of all species of vertebrates. Failure to maintain homeostasis of oxygen leads to damage to both the peripheral nervous system and central nervous system (CNS). The CNS is responsible for cognitive functions including learning and memory. In previous studies, findings suggest that the hippocampus involved in spatial learning and memory is also vulnerable to hypoxia. ${ }^{3}$ Hypoxia exposure has been shown to affect the hippocampus, causing memory impairment. ${ }^{4,5}$ Although previous findings strongly indicated that exposure to hypoxia induced memory loss, few studies have evaluated the protective effects of natural products and their compounds on memory loss after exposure to hypoxia.

Administration of exogenous antioxidants such as polyphenols and vitamin $E$ has been reported to be a potential way to combat the adverse effects of oxidative stress-induced hypoxia. ${ }^{6-16}$ In animal models and patients with impaired cognition, antioxidantrich diets or treatments prevent memory and learning deficits. ${ }^{17}$ Several approaches have been used to target oxidative stress including supplements such as blueberry extracts, ${ }^{18}$ melatonin, ${ }^{13,19}$ and vitamin E. ${ }^{20}$ Despite promising results from both rodent and human studies, much is still being studied regarding the benefit and role of specific nutritional supplements in the treatment of various hypoxic conditions. ${ }^{18,19,21}$

Numerous studies have demonstrated the beneficial effects of Tualang honey and its potential therapeutic applications as an antidiabetic, anticancer, and antimicrobial agent as well as its possessing wound healing properties. ${ }^{22}$ Moreover, Tualang honey enhances the hippocampal neuronal morphology and minimizes hippocampal neuronal damage. ${ }^{23}$ Tualang honey is rich in phenolic acid and contains antioxidant compounds such as quercetin and flavonoids. ${ }^{24} \mathrm{~A}$ recent study reported that Tualang honey improved brain function through the cholinergic system. ${ }^{25}$ Our previous studies concluded that Tualang honey improved memory performance in stressed ovariectomized rats, ${ }^{26}$ rats subjected to noise stress, ${ }^{27}$ and postmenopausal women $^{28}$ and decreased depressive-like behavior and increased brain-derived neurotrophic factor (BDNF) level in ovariectomized rats. ${ }^{29}$ Correspondingly, another study identified significantly reduced markers of oxidative stress and increased levels of antioxidative enzymes in brain tissue, further supporting the protective effect of Tualang honey against brain oxidative stress. ${ }^{30}$ However, to the best of our knowledge, no study has investigated the effect of Tualang honey on learning and memory of rats in hypoxic condition. Therefore, the present study aimed to evaluate the efficacy of Tualang honey in adult male Sprague Dawley rats to alleviate hypoxia-induced memory deficit.

\section{MATERIALS AND METHODS}

Forty-eight adult male Sprague Dawley rats were supplied by the Laboratory Animal Research Unit, Universiti Sains Malaysia (USM). The rats were approximately 8 weeks old with body weight of $200 \pm 20 \mathrm{~g}$. They were kept in polypropylene cages $(32 \times 24 \times 16 \mathrm{~cm})$ and had free access to food and water. The rats were exposed to $12-\mathrm{h}$ light/dark cycles and held at $23{ }^{\circ} \mathrm{C}$ room temperature. The experimental protocol followed internationally accepted principles for laboratory animal use and care, and was approved by the research and Ethics Committee of this university [USM/Animal Ethics Approval/2015/ (95) (609)].

\section{Experimental animals}

The four groups of rats were as follows: normoxia treated with sucrose $(n=12)$, normoxia treated with Tualang honey $(n=12)$, hypoxia treated with sucrose $(n=12)$, and hypoxia treated with Tualang honey $(n=12)$. Tualang honey $(1 \mathrm{~mL}$ of $0.2 \mathrm{~g} / \mathrm{kg}$ body weight ${ }^{23}$ and sucrose $(1 \mathrm{~mL} \text { of } 7.9 \%)^{31}$ were freshly prepared and administered via oral gavage to the rats daily for 14 days. The Tualang honey and sucrose used in this study were from single batch honey obtained from Federal Agricultural Marketing Authorities, Malaysia and Sigma-Aldrich, Inc., St. Louis, MO, USA, respectively. The total food intake and body weight of the rats were recorded throughout the experimental period.

\section{Hypoxia exposure}

The rats in the hypoxia groups were housed in an acrylic airtight chamber with $\sim 11 \% \mathrm{O}_{2}, \sim 25{ }^{\circ} \mathrm{C}$ temperature, and $\sim 76 \%$ humidity. The $\mathrm{O}_{2}$ content of $\sim 11 \%$ was generated by an HCA HYPO-002 high-altitude simulation system. The rats in the 
normoxia groups were kept in room condition. The rats' food intake and body weight change were recorded weekly.

\section{Behavioral tests}

The behavioral tests were performed before and after exposure to hypoxia or normoxia for 2 weeks. The experiments were conducted in a ventilated, dimly lit, and soundproof room. The room temperature was maintained at about $23^{\circ} \mathrm{C}$.

\section{Novel object recognition (NOR) test}

All rats were habituated to the open arena $(60 \times 60 \times 30 \mathrm{~cm})$. They were allowed to freely explore the arena for 10 min per session for 2 days. On the third day, two similar objects were placed and fixed in symmetrical position on the right and the left side of the arena, about $10 \mathrm{~cm}$ from the wall. The rats were allowed to freely explore the objects for $10 \mathrm{~min}^{32,33}$ The time spent to explore the objects was recorded manually.

The test sessions were carried out after 2 and $24 \mathrm{~h}$ for shortterm memory (STM) and long-term memory (LTM), respectively. During these sessions, familiar and novel objects were placed in the arena for $10 \mathrm{~min}$ and the time spent to explore each object was recorded. In order to avoid discrimination by olfactory cues, all the equipment was cleaned with $70 \%$ alcohol between each session. Object position was changed (right and left) to avoid place preference. The objects were made of plastic toys with a height of $5 \mathrm{~cm}$, and had similar textures, colors, and sizes but distinctive shapes. Sniffing or touching the object with the rat's nose was defined as exploration. ${ }^{34}$ Sitting on the object was not defined as exploration. ${ }^{34}$

The discrimination index was calculated based on the difference in exploration time between the novel and familiar objects and dividing it by the total exploration time of both objects. ${ }^{35}$ The index was used to measure recognition memory. ${ }^{36} \mathrm{~A}$ positive score means a preference for the novel object and indicates successful memory retention for the familiar object, while a negative score means a preference for the familiar object and indicates memory deficit. ${ }^{37}$

\section{T-maze}

The T-maze was made of black Perspex, was $30 \mathrm{~cm}$ in height, consisted of three arms (start arm: $60 \times 16.5 \mathrm{~cm}$; two goal arms: $50 \times 16.5 \mathrm{~cm}$ ), and was equipped with three doors. Before the experiment, the rats were placed in a room for at least $30 \mathrm{~min}$ to accustom them to it. The test was carried out in a single continuous session. It started with one-forced choice trial followed by 14 -free choice trials. ${ }^{38}$ During the forced-choice trial, the door was lowered to close the left or right goal arm. The rat was released from the start arm and was allowed to navigate the maze until it entered the open goal arm. Once the rat returned to the start position, it was detained for $5 \mathrm{~s}$ by lowering the door of the start arm. During the 14-free choice trials, the rat was released from the start arm and was free to enter either the right or left goal arm. Once the rat entered one goal arm, the other goal arm was closed immediately. After the rat returned to the start arm, it was again detained for $5 \mathrm{~s}$ in the start arm.
If the animal did not return to the start arm within 2 min, the door was used to gently push the rat to the start arm. The test session was terminated as soon as 14-free choice trials had been completed or 30 min had elapsed, whichever came first. In order to avoid discrimination by olfactory cues, all the equipment was cleaned with $70 \%$ alcohol between each session. The number of correct alternations out of the 14-forced trials was recorded and the rats that passed fewer than 8-freechoice trials within 30 min were excluded from the study.

\section{Morphological changes}

\section{Histological analysis}

Twenty-four hours after the last behavioral test, the rats were anesthetized using sodium pentobarbital $(0.27 \mathrm{~mL})$ (Alfasan, Woerden, Holland). Intracardiac perfusion with $0.1 \mathrm{M}$ phosphate-buffered saline (PBS) ( $\mathrm{pH}$ 0.7) for 2 min followed by $4 \%$ paraformaldehyde (PFA) ( $\mathrm{pH} 7.0$ ) for 3 min (Fisher Scientific, USA) was performed to prefix the tissue. The brain was carefully dissected, postfixed in 4\% PFA (Fisher Scientific, USA) and kept at $4{ }^{\circ} \mathrm{C}$ in the refrigerator. Then the brain tissues were subjected to paraffin sectioning following the standard protocol.

\section{Cresyl violet staining}

The paraffin section was dewaxed by immersion in xylene 1 and 2 solutions for 2 min each. After that, the slides were hydrated in decreasing dilutions of ethanol for 2 min each, immersed in cresyl violet for $3 \mathrm{~min}$, and then cleaned with distilled water to remove excess cresyl violet. Next, the slides were dehydrated in increasing dilutions of ethanol for 2 min each, immersed in xylene 1 and 2 for 2 min each, and finally left to dry for 30 min. The slides were then mounted in DPX mounting medium (BDH Chemicals, UK) and covered using coverslips (HmbG Inc., Germany). Finally, the slides were examined under a light microscope (Olympus Corporation, Japan) attached to an image analyzer (20x objective lens power) by three blinded investigators.

\section{Apoptosis detection by propidium iodide assay}

The paraffin sections were dewaxed, hydrated in decreasing dilutions of alcohol, and washed in PBS. The slides were gently dabbed on tissue paper to drain excess PBS. Then the slides were blocked by incubation in the blocking solution for $20 \mathrm{~min}$ in the dark. Before incubation in $25 \mu \mathrm{L}$ of buffer for $10 \mathrm{~min}$, the area around the sample was carefully wiped and washed in PBS. Next, $25 \mu \mathrm{L}$ of propidium iodide reagent was added to each slide for $30 \mathrm{~min}$ and then washed in PBS. The slides were then mounted in fluorescent mounting medium (Thermo Fisher Scientific, USA) and covered with coverslips (HmbG Inc., Germany). Finally, the slides were examined under a fluorescent microscope (Olympus Corporation, Japan) attached to an image analyzer under a green filter (20x objective lens power) by three blinded investigators.

\section{Statistical analysis}

Differences in the means of behavioral scores, food intake, and body weight among the experimental groups were analyzed 
using One-Way ANOVA with a Bonferroni post hoc test. Differences were regarded as significant at $p<0.05$.

\section{RESULTS}

\section{Changes in food intake}

There were no differences in food intake in normoxia animals, whereas hypoxia animals treated with sucrose and honey showed a significant $(p<0.05)$ reduction in food intake (Figure 1).

\section{Changes in body weight}

Following exposure to hypoxia, the body weight of the animals was significantly $(p<0.05)$ reduced in both the sucrose and honey treated groups (Figure 1).

\section{NOR test}

The results suggest that hypoxia adversely affects STM more than LTM. There was a significant improvement in the discrimination indexes of the STM and LTM tests following honey treatment, indicating that honey pretreatment was able to prevent the adverse effects of hypoxia on recognition memory functions, especially STM (Figure 2).

\section{T-maze}

The results suggest that hypoxia also affects the number of alterations in the T-maze. Similar to the NOR test, a significant improvement in the mean number of alterations in the T-maze was noted following honey treatment, suggesting the protective effects of honey pretreatment on spatial memory functions (Figure 2).

\section{Morphological changes}

Following the behavioral experiments, hippocampal morphology was analyzed using cresyl violet (Figures 3-6) and propidium iodide staining (Figures 7 and 8). The quantity analysis of CA1, CA2, CA3, and DG of the hippocampus showed significant ( $p<0.05)$ numbers of dead cells in the sucrose-treated hypoxic group, whereas the Tualang honey-treated hypoxic group of animals showed fewer dead cells, indicating that Tualang honey prevented neuronal damage (Figure 7). Cytoplasmic shrinkage and pyknotic nucleus are features indicative of a dead cell. For qualitative analysis to further confirm neuronal damage especially in the hypoxia groups treated with sucrose and honey, PI staining was carried out. The results displayed and reconfirmed that there was considerable neuronal damage in the hypoxia group treated with sucrose but not much in the hypoxia group treated with Tualang honey (Figure 8).

\section{DISCUSSION}

We present three important findings in the present study. First, continuous exposure to normobaric hypoxia for 7 days exerted adverse effects on food intake, body weight gain, and memory performance. Second, with regard to memory function, STM, LTM, and spatial memory performance were significantly affected. Third, Tualang honey pretreatment was able to protect against hypoxia-induced memory deficits and hippocampal neuronal damage. Regarding food intake, hypoxic animals treated with sucrose and honey consumed significantly less food than normoxia animals treated with sucrose and honey. Numerous previous studies support the present findings that high altitude exposure is associated with a reduction in food intake. ${ }^{39}$ Westerterp-Plantenga et al. ${ }^{40}$ demonstrated that high altitude causes hypophagia and reported it as being more specific to carbohydrate ${ }^{41}$ and protein. ${ }^{42}$ Not only humans subjected to high altitude experience hypophagia but also animals exhibit changes in feeding behavior following exposure to hypobaric hypoxia, whereby reductions in food intake are directly linked to the degree of simulated altitude. ${ }^{43}$
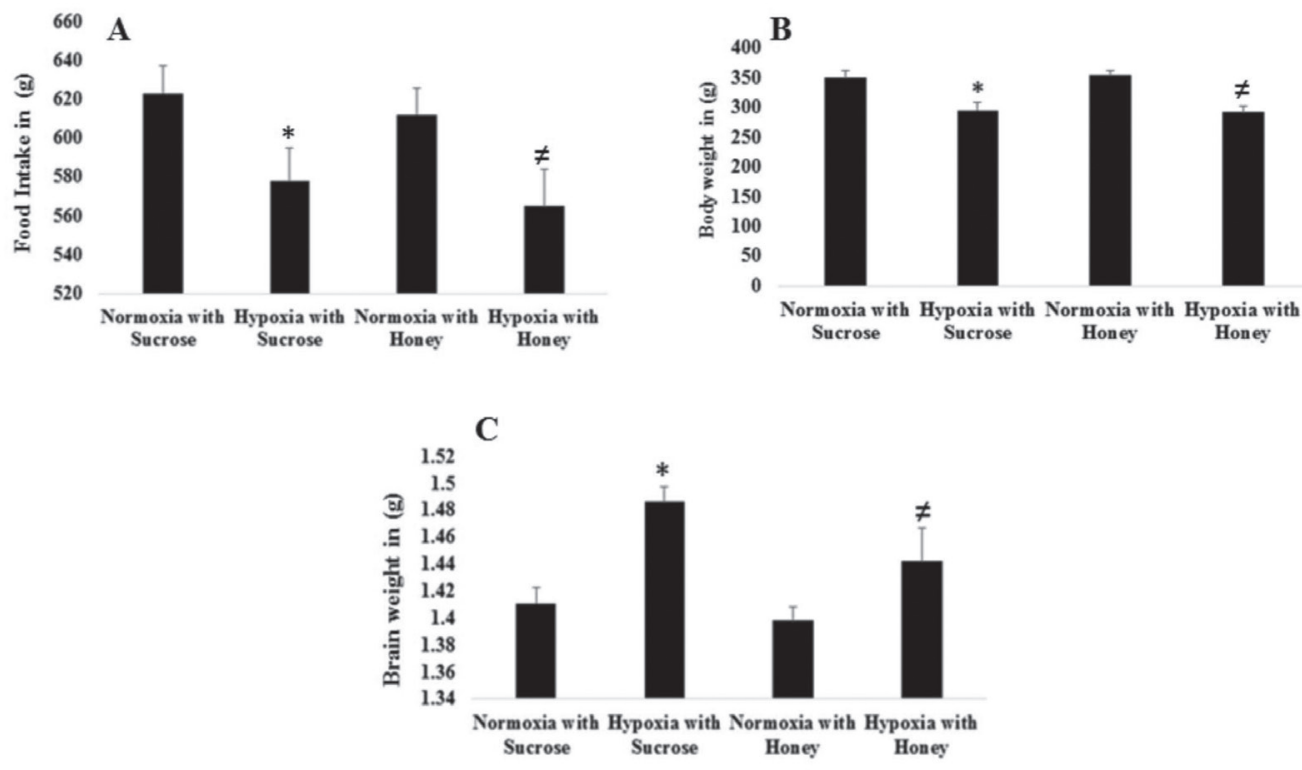

Figure 1. Food intake A), body weight B), and brain weight C) following exposure to hypoxia. The data are displayed as mean (SEM). ${ }^{\star} p<0.05$ vs. normoxia with sucrose, $\neq$ p $<0.05$ vs. normoxia with honey 

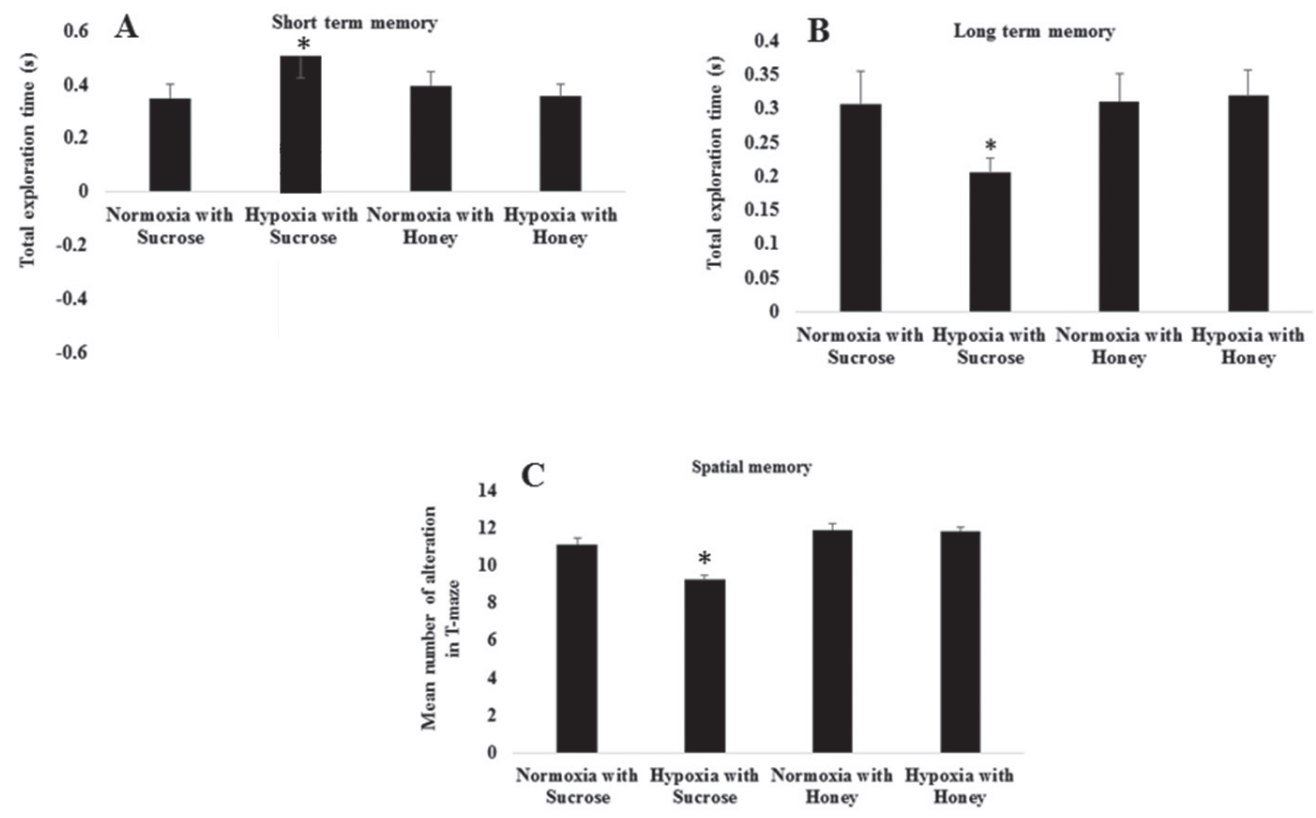

Figure 2. Short-term memory A), long-term memory B), and spatial memory C) following exposure to hypoxia. The data are displayed as mean (SEM). ${ }^{*}$ p $<0.05$ vs normoxia with sucrose

SEM: Standard error of the mean
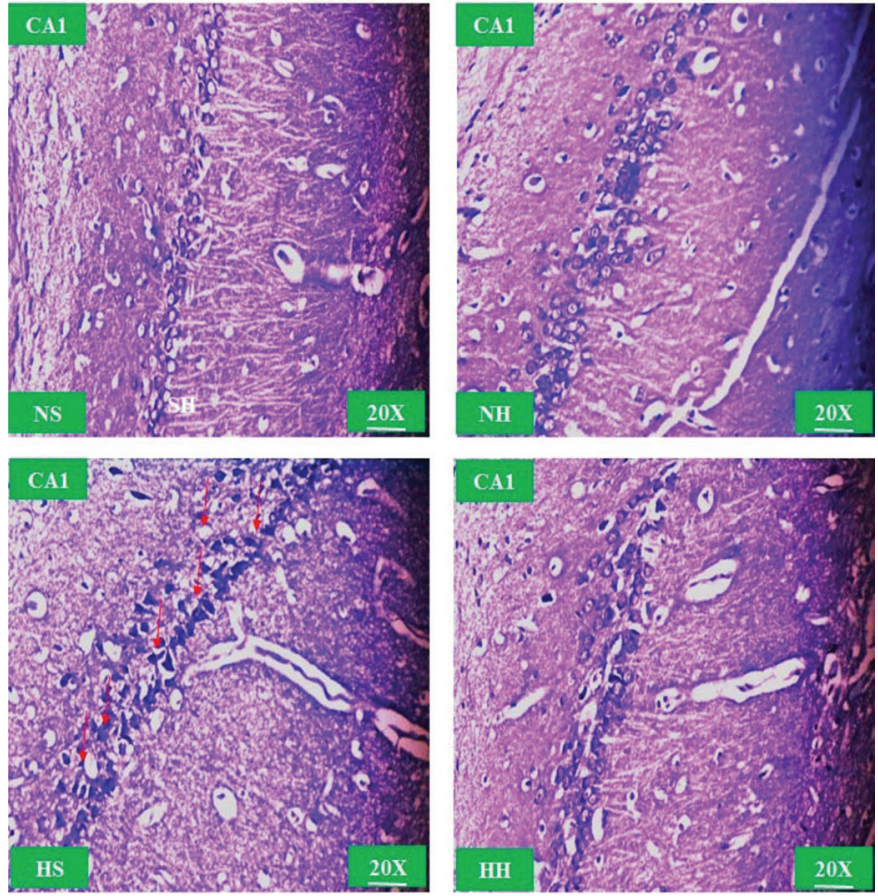

Figure 3. Morphological changes in CA1 of the hippocampus in normoxia sucrose (NS), normoxia honey (NH), hypoxia treated with sucrose (HS), and hypoxia treated with honey $(\mathrm{HH})$. Neuronal damage indicated with red arrow. Cytoplasmic shrinkage and pyknotic nucleus indicate dead cells. Bar scale $200 \mu \mathrm{m}$

As a result of the decrease in food intake, animals exposed to hypoxia display a substantial reduction in body weight in both sucrose and honey treated groups. Loss of appetite could be one of the possibilities for the reduction in body weight. ${ }^{44}$ Hypoxia also affects body weight regulation as noted in humans as well
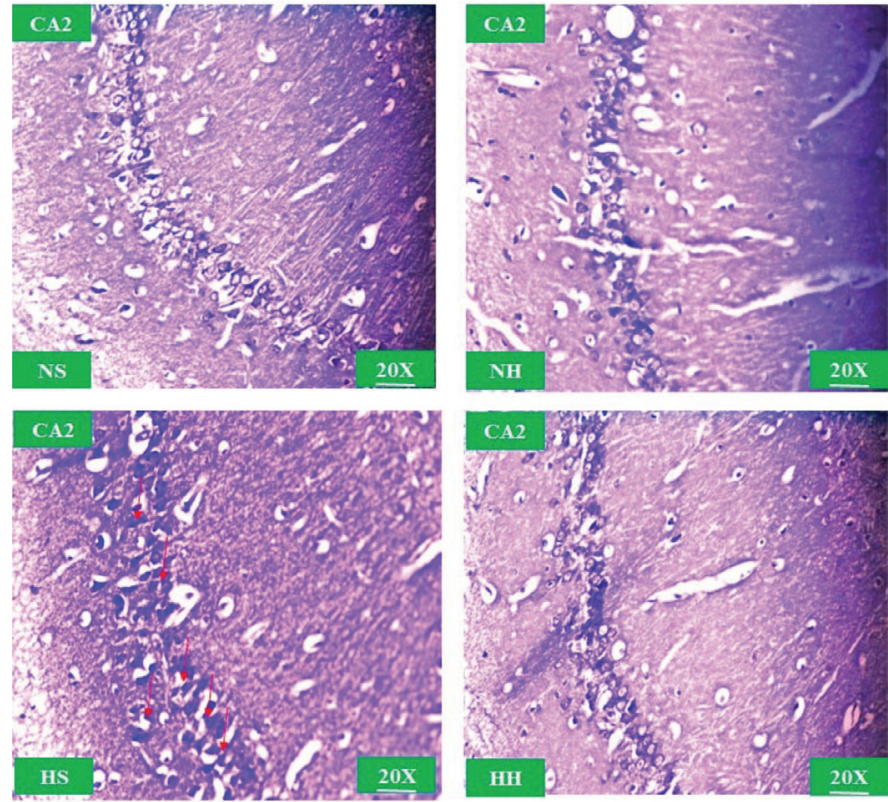

Figure 4. Morphological changes in CA2 of the hippocampus in normoxia sucrose (NS), normoxia honey (NH), hypoxia treated with sucrose (HS), and hypoxia treated with honey $(\mathrm{HH})$. Neuronal damage indicated with red arrow. Cytoplasmic shrinkage and pyknotic nucleus indicate dead cells. Bar scale $200 \mu \mathrm{m}$

as in animals. ${ }^{45}$ Similar findings were obtained in the present study, in which the food intake and body weight gain were lower in the rats exposed to hypoxia compared to the nonhypoxic rats. The poor appetite and decreased food intake often produce an imbalance in the energy equation that leads to low weight gain and changes in body composition. ${ }^{46}$ The proposed mechanisms include changes in leptin, glucagon-like peptide 1 , 


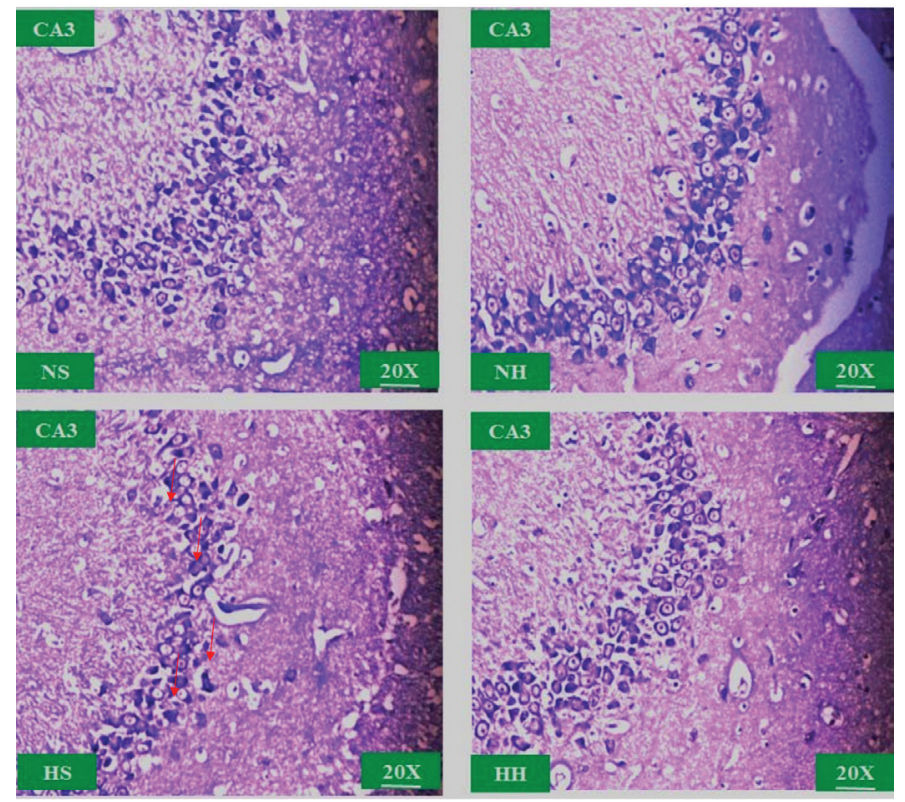

Figure 5. Morphological changes in CA3 of the hippocampus in normoxia sucrose (NS), normoxia honey $(\mathrm{NH})$, hypoxia treated with sucrose (HS), and hypoxia treated with honey $(\mathrm{HH})$. Neuronal damage indicated with red arrow. Cytoplasmic shrinkage and pyknotic nucleus indicate dead cells. Bar scale $200 \mu \mathrm{m}$
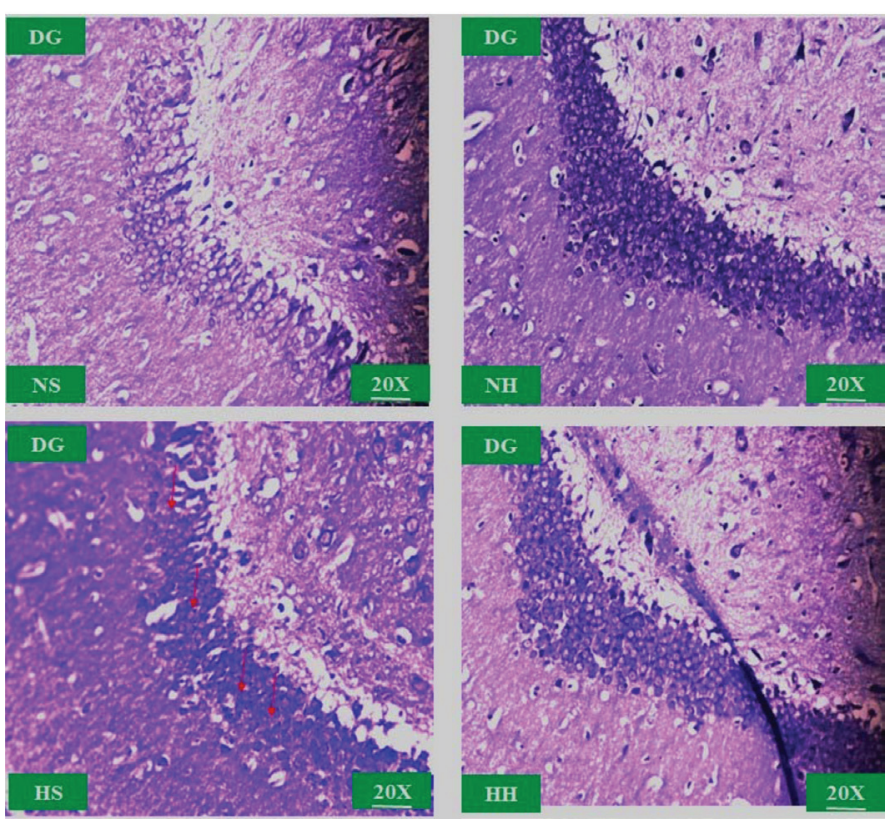

Figure 6. Morphological changes in DG of the hippocampus in normoxia sucrose (NS), normoxia honey $(\mathrm{NH})$, hypoxia treated with sucrose $(\mathrm{HS}$ ), and hypoxia treated with honey $(\mathrm{HH})$. Neuronal damage indicated with red arrow. Cytoplasmic shrinkage and pyknotic nucleus indicate dead cells. Bar scale $200 \mu \mathrm{m}$

protein synthesis, intestinal absorption, and hypoxia-regulated genes. ${ }^{47}$ Moreover, previous work suggested leptin as the main candidate for the reduction in food intake following hypoxia. ${ }^{44}$ However, the role of leptin and food intake during hypoxia is still a subject of debate and the mechanisms responsible for the decrease in energy intake in hypoxia conditions remain unclear.
Despite the hypoxic groups of animals displaying a reduction in food intake and body weight, these groups did not show any kind of locomotor deficits in the open field test. Hence, the recognition objective memory test was carried out following exposure to hypoxia. Interestingly, the hypoxia group treated with Tualang honey showed improvement in recognition objective memory performance, whereas the hypoxia group treated with sucrose failed to retain memory function. There were no significant changes found in the normoxia rats treated with sucrose and Tualang honey. Many previous studies used a hypoxic chamber set at $6-8 \%$ of oxygen content for a shorter time and found significant memory deficit. ${ }^{47,48}$ Reducing the oxygen content to $6 \%$ impaired acquisition of the avoidance response, and the significant difference between the percentages of avoidance responses of animals placed in normoxic and hypoxic conditions on day 3 were $69.2 \%$ and $38.0 \%$, respectively. This finding was in line with an earlier report by Saligaut et al. ${ }^{47}$ in which the acquisition of a conditioned avoidance response was impaired under $8 \%$ oxygen content (300 torr) of hypobaric hypoxia.

Our results, along with those of previous studies, clearly indicated that both normoxic and hypobaric hypoxia were able to induce memory deficits. Thus, this equivalent air altitude model'49 can also be used to study memory function despite earlier reported physiological differences between acute exposures to normobaric and hypobaric hypoxia. ${ }^{50}$ In the present study, two behavioral tests were carried out, i.e. spatial working memory and recognition memory. Rats that were exposed to hypoxia displayed deficits in STM, LTM, and spatial memory. Such findings are consistent with earlier evidence that hypoxic exposure impaired visual memory and spatial memory. ${ }^{51-58}$ Interestingly, the present study demonstrated that pretreatment with Tualang honey was able to protect the rats against hypoxia-induced memory deficits as revealed by the behavioral output that was comparable to that of the controls.

Numerous studies have reported that exposure to hypoxia triggers memory deficits through involvement of various mechanisms. ${ }^{56,59}$ In particular, neuronal apoptosis in the cortex, striatum, and hippocampal cells; ${ }^{53}$ imbalance in oxidative and antioxidative enzymes; ${ }^{60}$ and alteration in cholinergic ${ }^{55}$ and glutamate neurotransmission ${ }^{61}$ might be the root cause of impairment of spatial working memory during exposure to hypoxia. However, the potential therapeutic method to reduce these changes during hypoxia has not been evaluated. The present results suggested that Tualang honey treatment could improve memory following exposure to hypoxia. Hence, Tualang honey could potentially be a way to mitigate deleterious effects following hypoxia.

A broad range of studies have been carried out in Asian countries to analyze the chemical composition of Tualang honey as well as its functional properties. ${ }^{22,23,62}$ Tualang honey has been reported to possess high flavonoid content, including quercetin, luteolin, kaempferol, apigenin, chrysin, and galangin. ${ }^{63}$ Likewise, honey, in general, contains enzymatic and nonenzymatic antioxidants. ${ }^{64-66}$ Based on the present results, memory performance improved after hypoxia exposure in 

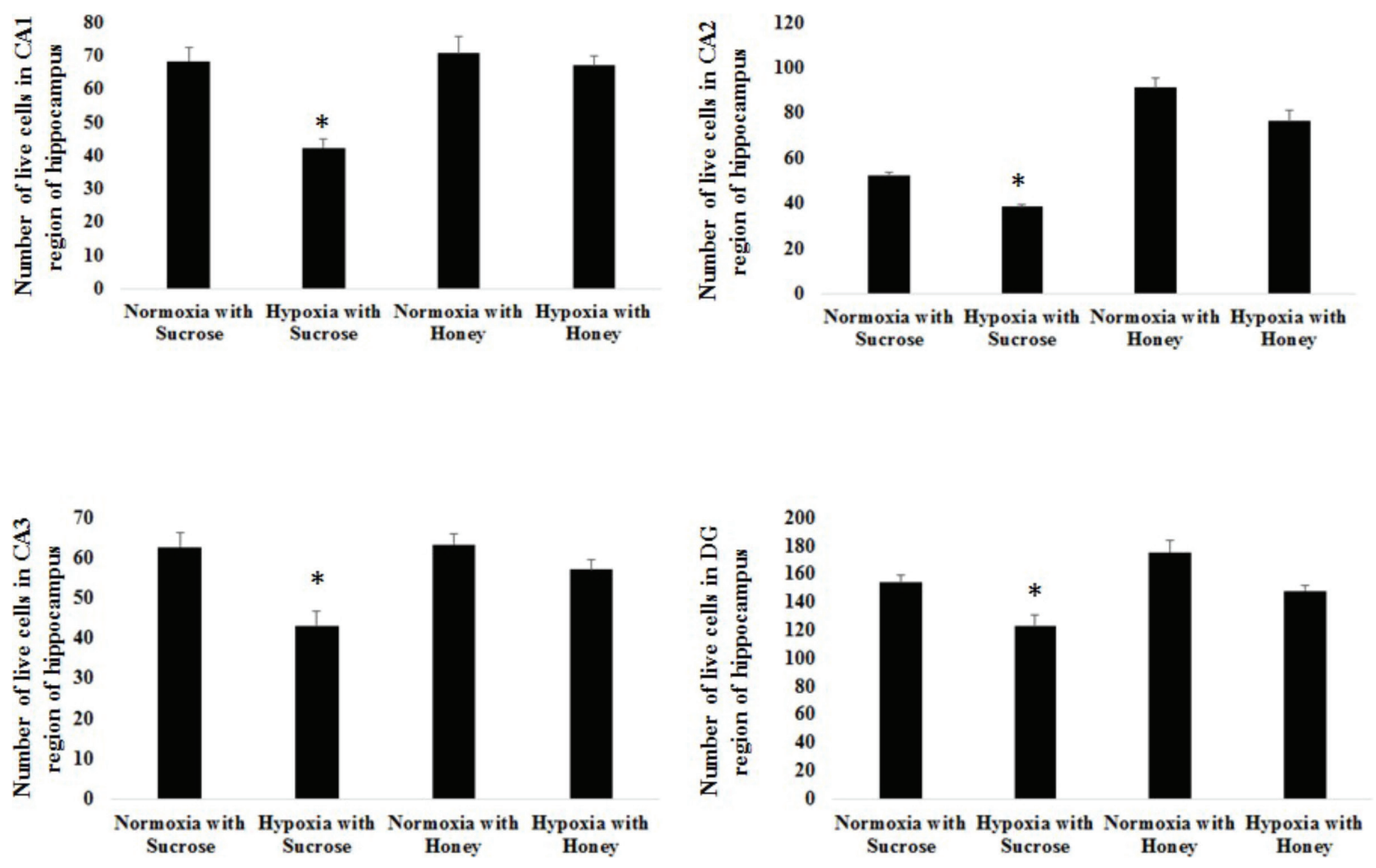

Figure 7. Quantification of neuronal damage in CA1, CA2, CA3 and DG of the hippocampus. The data are displayed as mean (SEM). ${ }^{*}<0.05$ vs normoxia with sucrose

SEM: Standard error of the mean

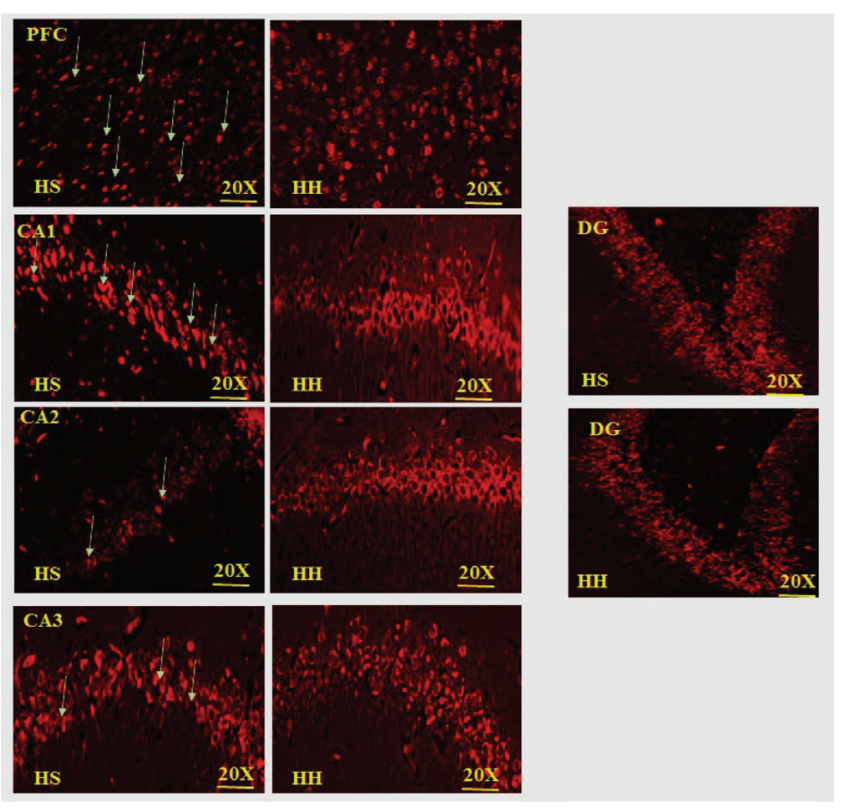

Figure 8. The apoptotic dead cells using PI staining in PFC and CA1, CA2, CA3, and DG of the hippocampus in hypoxia treated with sucrose (HS) and hypoxia treated with honey $(\mathrm{HH})$. Neuronal damage indicated with arrows. Cytoplasmic shrinkage and pyknotic nucleus indicate dead cells. Bar scale $200 \mu \mathrm{m}$

Tualang honey treated groups through modulation of oxidative stress. Previous studies reported that Tualang honey decreased oxidative stress caused by kainic acid. ${ }^{62}$ It also shows antioxidant properties in streptozotocin-induced diabetic rats. ${ }^{22}$ In human subjects, Tualang honey treatment in healthy postmenopausal women resulted in an improvement in memory. ${ }^{28} \mathrm{Al}$-Rahbi et al. ${ }^{23}$ also reported that Tualang honey treatment improved memory in animals subjected to instability stress. Al-Rahbi et al. ${ }^{23}$ reported that Tualang honey supplement improves memory performance and prevents neuronal damage in hippocampal regions. A recent study reported that in female athletes Tualang honey showed antioxidant activity and oxidative stress in a dose-dependent manner. ${ }^{67}$ Tualang honey was also found to protect the rat midbrain from oxidative stress. ${ }^{68}$ Azman et al. ${ }^{27,69}$ demonstrated that Tualang honey prevented memory deficits following noise stress. An in vitro study also stated that Tualang honey improved cell migration and resistance against oxidative stress. ${ }^{70}$ Not only does Tualang honey control oxidative stress but it also enhances the level of BDNF, ${ }^{29}$ which could be one of the mechanisms involved in the improvement of memory during hypoxia. However, this needs further exploration.

Brain weight and morphological changes were also studied following exposure to hypoxia. The results suggested that the weight of the brain following hypoxia significantly increased in the hypoxia group treated with sucrose but not in the hypoxia group treated with Tualang honey. Mórocz et al. ${ }^{71}$ reported that brain volume changes occur in patients following exposure to hypoxia due to changes in cerebral blood volume. Another important factor is the occurrence of brain edema due to the 
inflammatory process following acute exposure to hypoxia. ${ }^{72}$ In the present study, we did not evaluate the factors that could contribute to edema but the increased brain weight indicates this. The hippocampal morphological changes were analyzed in CA1, CA2, CA3, and DG. The hypoxia group treated with sucrose showed a significant number of dead cells as compared to the hypoxia group treated with Tualang honey. It is assumed that Tualang honey prevents neuronal damage through reduction of oxidative stress. It is possible that its antioxidant content contributes to minimizing the neuronal damage and improving memory. ${ }^{31}$ It is thought that Tualang honey prevents hippocampal neuronal damage through phenolic acid, which has an antioxidant property. ${ }^{73}$ Phenolic antioxidants attenuate the hippocampal neuronal cell damage induced by excitotoxicity. ${ }^{74}$ We postulate that the superior therapeutic performance seen in Tualang honey treated rats in hypoxic condition was due to many antioxidant components and other components involved to improve memory through prevention of neuronal damage.

Taking together all findings in the present study, Tualang honey could improve memory and prevent neuronal damage due to hypoxia, possibly through mechanisms involving its antioxidant properties bringing about these effects. To the best of our knowledge, this is the first time that Tualang honey has been evaluated under hypoxic condition using rats. For better understanding regarding the underlying mechanisms whereby Tualang honey improves memory and prevents neuronal damage, further studies are warranted.

\section{CONCLUSION}

We propose that Tualang honey pretreatment potentially has protective effects against memory deficits triggered by hypoxia through its antioxidant content.

\section{ACKNOWLEDGEMENTS}

This research work was supported by a short-term grant from Universiti Sains Malaysia; 304/PPSP/61313086.

Conflicts of interest: No conflict of interest was declared by the authors. The authors alone are responsible for the content and writing of the paper.

\section{REFERENCES}

1. Mórocz IA, Zientara GP, Gudbjartsson H, Muza S, Lyons T, Rock PB, Kikinis R, Jólesz FA. Volumetric quantification of brain swelling after hypobaric hypoxia exposure. Exp Neurol. 2001;168:96-104.

2. Muthuraju S, Maiti P, Solanki P, Sharma AK, Amitabh, Singh SB, Prasad $D$, llavazhagan G. Acetylcholinesterase inhibitors enhance cognitive functions in rats following hypobaric hypoxia. Behav Brain Res. 2009;203:1-14.

3. Maiti P, Singh SB, Mallick B, Muthuraju S, Ilavazhagan G. High altitude memory impairment is due to neuronal apoptosis in hippocampus, cortex and striatum. J Chem Neuroanat. 2008;36:227-238.

4. Malle C, Quinette P, Laisney M, Bourrilhon C, Boissin J, Desgranges B, Eustache F, Piérard C. Working memory impairment in pilots exposed to acute hypobaric hypoxia. Aviat Space Environ Med. 2013;84:773-779.
5. Qaid E, Zakaria R, Sulaiman SF, Yusof NM, Shafin N, Othman Z, Ahmad $\mathrm{AH}$, Aziz CA. Insight into potential mechanisms of hypobaric hypoxiainduced learning and memory deficit - Lessons from rat studies. Hum Exp Toxicol. 2017;36:1315-1325.

6. Kempermann G, Kuhn HG, Gage FH. More hippocampal neurons in adult mice living in an enriched environment. Nature. 1997;386:493-495.

7. Kempermann G, Kuhn HG, Gage FH. Experience-induced neurogenesis in the senescent dentate gyrus. J Neurosci. 1998;18:3206-3212.

8. van Praag H, Christie BR, Sejnowski TJ, Gage FH. Running enhances neurogenesis, learning, and long-term potentiation in mice. Proc Natl Acad Sci USA. 1999;96:13427-13431.

9. van Praag H, Kempermann G, Gage FH. Running increases cell proliferation and neurogenesis in the adult mouse dentate gyrus. Nat Neurosci. 1999;2:266-270.

10. Hartley R, Castro-S'anchez R, Ramos-Gonzalez B, Bustos-Obreg E. Rat spermatogenesis damage in intermittent hypobaric hypoxia and the protective role of melatonin. I Cauda epididymal spermatozoa. Int J Morphol. 2009;27:1275-1284.

11. Radák Z, Lee K, Choi W, Sunoo S, Kizaki T, Oh-ishi S, Suzuki K, Taniguchi $\mathrm{N}$, Ohno H, Asano K. Oxidative stress induced by intermittent exposure at a simulated altitude of $4000 \mathrm{~m}$ decreases mitochondrial superoxide dismutase content in soleus muscle of rats. Eur J Appl Physiol Occup Physiol. 1994;69:392-395.

12. Nakanishi K, Tajima F, Nakamura A, Yagura S, Ookawara T, Yamashita $\mathrm{H}$, Suzuki K, Taniguchi N, Ohno H. Effects of hypobaric hypoxia on antioxidant enzymes in rats. J Physiol. 1995;489:869-876.

13. Farías JG, Zepeda AB, Calaf GM. Melatonin protects the heart, lungs and kidneys from oxidative stress under intermittent hypobaric hypoxia in rats. Biol Res. 2012;45:81-85.

14. Farías JG, Puebla M, Acevedo A, Tapia PJ, Gutierrez E, Zepeda A, Calaf G, Juantok C, Reyes JG. Oxidative stress in rat testis and epididymis under intermittent hypobaric hypoxia: protective role of ascorbate supplementation. J Androl. 2010;31:314-321.

15. Kücükakin B, Gögenur I, Rosenberg J. Melatonin against surgical stress. Ugeskr Laeger. 2007;169:1306-1308.

16. Wright VP, Klawitter PF, Iscru DF, Merola AJ, Clanton TL. Superoxide scavengers augment contractile but not energetic responses to hypoxia in rat diaphragm. J Appl Physiol. 2005;98:1753-1760.

17. Vauzour D, Vafeiadou K, Rodriguez-Mateos A, Rendeiro C, Spencer JP. The neuroprotective potential of flavonoids: a multiplicity of effects. Genes Nutr. 2008;3:115-126.

18. Zepeda AB, Aguayo LG, Fuentealba J, Figueroa CA, Salgado PK, Calaf GM, Farías J. Blueberry extracts protect testis from hypobaric hypoxia induced oxidative stress in rats. Oxid Med Cell Longev. 2012;2012:975870.

19. Bustos-Obreg'on E, Castro-S'anchez R, Ramos-Gonz'alez B, TorresD'ıaz L. Rat spermatogenesis damage in intermittent hypobaric hypoxia and the protective role of melatonin. II: Testicular parameters. Int J Morphol. 2010;28:537-547.

20. Wu A, Ying Z, Gomez-Pinilla F. Dietary omega-3 fatty acids normalize BDNF levels, reduce oxidative damage, and counteract learning disability after traumatic brain injury in rats. J Neurotrauma. 2004;21:1457-1467.

21. Vauzour D, Vafeiadou K, Rodriguez-Mateos A, Rendeiro C, Spencer JP. The neuroprotective potential of flavonoids: a multiplicity of effects. Genes Nutri. 2008;3:115-126. 
22. Erejuwa OO, Sulaiman SA, Wahab MS, Sirajudeen KN, Salleh MS, Gurtu $\mathrm{S}$. Antioxidant protection of Malaysian tualang honey in pancreas of normal and streptozotocin-induced diabetic rats. Ann Endocrinol (Paris). 2010;71:291-296.

23. Al-Rahbi B, Zakaria R, Othman Z, Hassan A, Mohd Ismail ZI, Muthuraju S. Tualang honey supplement improves memory performance and hippocampal morphology in stressed ovariectomized rats. Acta Histochem. 2014;116:79-88.

24. Khalil MI, Alam N, Moniruzzaman M, Sulaiman SA, Gan SH. Phenolic acid composition and antioxidant properties of Malaysian honeys. J Food Sci. 2011;76(6):C921-8. doi:10.1111/j.1750-3841.2011.02282.x. PMID: 22417491.

25. Al-Rahbi B, Zakaria R, Othman Z, Hassan A, Ahmad AH. The effects of Tualang Honey Supplement on Medial Prefrontal Cortex Morphology and Cholinergic System in Stressed Ovariectomised Rats. Int. J Appl Res Nat Prod. 2014;7:28-36.

26. Al-Rahbi B, Zakaria R, Othman Z, Hassan A, Muthuraju S, Wan Mohammad WM. Mood and memory function in ovariectomised rats exposed to social instability stress. Biomed Res Int. 2013;2013:493643.

27. Azman KF, Zakaria R, Ab Aziz CB, Othman Z, Al-Rahbi B. Tualang honey improves memory performance and decreases depressivelike behaviours in rats exposed to loud noise stress. Noise Health. 2015;17:83-89.

28. Othman Z, Shafin N, Zakaria R, Hussain NH, Mohammad WM. Improvement in immediate memory after 16 weeks of tualang honey (Agro Mas) supplement in healthy postmenopausal women. Menopause. 2011;18:1219-1224.

29. Al-Rahbi B, Zakaria R, Othman Z, Hassan A, Ahmad AH. Enhancement of BDNF concentration and restoration of the hypothalamic-pituitaryadrenal axis accompany reduced depressive-like behaviour in stressed ovariectomised rats treated with either Tualang honey or estrogen. Scientific World Journal. 2014;2014:310821.

30. Al-Rahbi B, Zakaria R, Othman Z, Hassan A, Ahmad AH. Protective Effects of Tualang Honey against Oxidative Stress and Anxiety-Like Behaviour in Stressed Ovariectomized Rats. Int Sch Res Notices. 2014:2014:521065.

31. Chepulis LM, Starkey NJ, Waas JR, Molan PC. The effects of long-term honey, sucrose or sugar-free diets on memory and anxiety in rats. Physiol Behav. 2009;97:359-368.

32. De Lima MN, Laranja DC, Bromberg E, Roesler R, Schröder N. Preor post-training administration of the NMDA receptor blocker MK801 impairs object recognition memory in rats. Behav Brain Res. 2005;156:139-143.

33. Pieta Dias C, Martins De Lima MN, Presti-Torres J, Dornelles A, Garcia VA, Siciliani Scalco F, Rewsaat Guimarães M, Constantino L, Budni P, Dal-Pizzol F, Schröder N. Memantine reduces oxidative damage and enhances long-term recognition memory in aged rats. Neuroscience. 2007;146:1719-1725.

34. Bowman R, Ferguson D, Luine V. Effects of chronic restraint stress and estradiol on open field activity, spatial memory, and monoaminergic neurotransmitters in ovariectomized rats. Neurosci. 2002;113:401-410.

35. Reneerkens OAH, Rutten K, Akkerman S, Blokland A, Shaffer CL, Menniti FS, Steinbusch HW, Prickaerts J. Phosphodiesterase type 5 (PDE5) inhibition improves object recognition memory: Indications for central and peripheral mechanisms. Neurobiol Learn Mem. 2012;97:370-379.
36. Kamei H, Nagai T, Nakano H, Togan Y, Takayanagi M, Takahashi K, Kobayashi K, Yoshida S, Maeda K, Takuma K, Nabeshima T, Yamada K. Repeated methamphetamine treatment impairs recognition memory through a failure of novelty-induced ERK1/2 activation in the prefrontal cortex of mice. Biol Psychiatry. 2006;59:75-84.

37. Carlini VP, Martini AC, Schiöth HB, Ruiz RD, Fiol de Cuneo M, de Barioglio SR. Decreased memory for novel object recognition in chronically food-restricted mice is reversed by acute ghrelin administration. Neuroscience. 2008;153:929-934.

38. Spowart-Manning L, van der Staay FJ. The T-maze continuous alternation task for assessing the effects of putative cognition enhancers in the mouse. Behav Brain Res. 2004;151:37-46.

39. Tschop M, Strasburger CJ, Hartmann G, Biollaz J, Bartsch P. Raised leptin concentrations at high altitude associated with loss of appetite. Lancet. 1998;352:1119-1120.

40. Westerterp-Plantenga MS, Westerterp KR, Rubbens M, Verwegen CR, Richelet JP, Gardette B. Appetite at "high altitude" [Operation Everest III (Comex-'97)]: a simulated ascent of Mount Everest. J Appl Physiol. 1999;87:391-399.

41. Rose MS, Houston CS, Fulco CS, Coates G, Sutton JR, Cymerman A. Operation Everest. II: Nutrition and body composition. J Appl Physiol. 1988;65:2545-2551.

42. Armellini F, Zamboni M, Robbi R, Todesco T, Bissoli L, Mino A, Angelini G, Micciolo R, Bosello O. The effects of high altitude trekking on body composition and resting metabolic rate. Horm Metab Res. 1997;29:458461.

43. Elia R, Elgoyhen AB, Bugallo G, Rio ME, Bozzini CE. Effect of exposure to reduced atmospheric pressure on body weight, food intake and body composition of growing rats. Acta Physiol Pharmacol Latinoam. 1985;35:311-318.

44. Norese MF, Lezón CE, Alippi RM, Martínez MP, Conti MI, Bozzini CE. Failure of polycythemia-induced increase in arterial oxygen content to suppress the anorexic effect of simulated high altitude in the adult rat. High Alt Med Biol. 2002;3:49-57.

45. Quintero P, Milagro FI, Campión J, Martínez JA. Impact of oxygen availability on body weight management. Med Hypotheses. 2010;74:901907.

46. Westerterp KR. Energy and water balance at high altitude. News Physiol Sci. 2001;16:134-137.

47. Saligaut C, Moore N, Boulu R, Plotkine M, Leclerc JL, Prioux-Guyonneau $M$, Boismare F. Hypobaric hypoxia: Central catecholamine levels and cortical $\mathrm{PO}_{2}$ and avoidance response in rats treated with apomorphine. Aviat Space Environ Med. 1981;52:166-170.

48. Groo D, Palosi E, Szporny L. Comparison of the effects of vinpocetine, vincamine, and nicergoline on the normal and hypoxia-damaged learning process in spontaneously hypertensive rats. Drug Dev Res. 1988;15:75-85.

49. Bert P. Barometric pressure: researches in experimental physiology. Bethesda Md, Undersea and Hyperbaric Medical Society, Forgotten Books;1978:362-367

50. Coppel J, Hennis P, Gilbert-Kawai E, Grocott MP. The physiological effects of hypobaric hypoxia versus normobaric hypoxia: a systematic review of crossover trials. Extrem Physiol Med. 2015;4:2.

51. Crow TJ, Kelman GR. Effect of mild acute hypoxia on human short-term memory. Br J Anaesth. 1971;43:548-552. 
52. Hota SK, Barhwal K, Baithar I, Prasad D, Singh SB, Ilavazhagan G. Bacopa monniera leaf extract ameliorates hypobaric hypoxia induced spatial memory impairment. Neurobiol. 2009;34:23-39.

53. Maiti P, Muthuraju S, llavazhagan G, Singh SB. Hypobaric hypoxia induces dendritic plasticity in cortical and hippocampal pyramidal neurons in rat brain. Behav Brain Res. 2008;189:233-243.

54. Barhwal K, Hota SK, Jain V, Prasad D, Singh SB, Ilavazhagan G. Acetyl-I-carnitine (ALCAR) prevents hypobaric hypoxia-induced spatial memory impairment through extracellular related kinase-mediated nuclear factor erythroid 2-related factor 2 phosphorylation. Neurosci 2009;161:501-514.

55. Muthuraju S, Maiti P, Solanki P, Sharma AK, Amitabh, Singh SB, Prasad D, llavazhagan G. Acetylcholinesterase inhibitors enhance cognitive functions in rats following hypobaric hypoxia. Behav Brain Res. 2009;203:1-14.

56. Muthuraju S, Maiti P, Solanki P, Sharma AK, Singh SB, Prasad D, Ilavazhagan G. Cholinesterase inhibitors ameliorate spatial learning deficits in rats following hypobaric hypoxia. Exp Brain Res. 2010;203:583-592.

57. Kauser H, Sahu S, Kumar S, Panjwani U. Guanfacine is an effective countermeasure for hypobaric hypoxia-induced cognitive decline. Neurosci. 2013;254:110-119.

58. Kauser H, Sahu S, Kumar S, Panjwani U. Guanfacine ameliorates hypobaric hypoxia induced spatial working memory deficits. Physiol Behav. 2014;123:187-192.

59. Muthuraju S, Maiti P, Pati S, Solanki P, Sharma AK, Singh SB, Prasad D, llavazhagan $G$. Role of cholinergic markers on memory function of rats exposed to hypobaric hypoxia. Eur J Pharmacol. 2011;672:96-105.

60. Jayalakshmi K, Singh SB, Kalpana B, Sairam M, Muthuraju S, Ilavazhagan G. N-acetyl cysteine supplementation prevents impairment of spatial working memory functions in rats following exposure to hypobaric hypoxia. Physiol Behav. 2007;92:643-650.

61. Hota SK, Barhwal K, Ray K, Singh SB, Ilavazhagan G. Ceftriaxone rescues hippocampal neurons from excitotoxicity and enhances memory retrieval in chronic hypobaric hypoxia. Neurobiol Learn Mem. 2008;89:522-532.

62. Sairazi NSM, Sirajudeen KNS, Asari MA, Mummedy S, Muzaimi M, Sulaiman SA. Effect of tualang honey against KA-induced oxidative stress and neurodegeneration in the cortex of rats. BMC Complement Altern Med. 2017;17:31.
63. Bogdanov S, Jurendic T, Sieber R, Gallmann P. Honey for nutrition and health: A review. J Am Coll Nutr. 2008;27:677-689.

64. Gheldof N, Engeseth NJ. Antioxidant capacity of honeys from various floral sources based on the determination of oxygen radical absorbance capacity and inhibition of in vitro lipoprotein oxidation in human serum samples. J Agric Food Chem. 2002;50:3050-3055.

65. Al ML, Daniel D, Moise A, Bobis O, Laslo L, Bogdanov S. Physicochemical and bioactive properties of different floral origin honeys from Romania. Food Chem. 2009;112:863-867.

66. Ferreira IC, Aires E, Barreira JC, Estevinho LM. Antioxidant activity of Portuguese honey samples: Different contributions of the entire honey and phenolic extract. Food Chem. 2009;114:1438-1443.

67. Ahmad NS, Abdul Aziz A, Kong KW, Hamid MSA, Cheong JPG, Hamzah $\mathrm{SH}$. Dose-response effect of tualang honey on postprandial antioxidant activity and oxidative stress in female athletes: A pilot study. J Altern Complement Med. 2017;23:989-995

68. Tang SP, Sirajudeen KNS, Jaafar $H$, Gan SH, Muzaimi M, Sulaiman SA. Tualang honey protects the rat midbrain and lung against repeated paraquat exposure. Oxid Med Cell Longev. 2017;2017:4605782.

69. Azman KF, Zakaria R, Ab Aziz CB, Othman Z. Tualang honey attenuates noise stress-induced memory deficits in aged rats. Oxid Med Cell Longev. 2016;2016:1549158. doi:10.1155/2016/1549158.

70. Tan JJ, Azmi SM, Yong YK, Cheah HL, Lim V, Sandai D, Shaharuddin B. Tualang honey improves human corneal epithelial progenitor cell migration and cellular resistance to oxidative stress in vitro. PLoS One. 2014;9:e96800.

71. Mórocz IA, Zientara GP, Gudbjartsson H, Muza S, Lyons T, Rock PB, Kikinis $R$, Jólesz FA. Volumetric quantification of brain swelling after hypobaric hypoxia exposure. Exp Neurol. 2001;168:96-104.

72. Zhou $Y$, Huang $X$, Zhao T, Qiao M, Zhao X, Zhao M, Xu L, Zhao Y, Wu L, Wu K, Chen R, Fan M, Zhu L. Hypoxia augments LPS-induced inflammation and triggers high altitude cerebral oedema in mice. Brain Behav Immun. 2017;64:266-275.

73. Kishore RK, Halim AS, Syazana MS, Sirajudeen KNS. Tualang honey has higher phenolic content and greater radical scavenging activity compared with other honey sources. Nutr Res. 2011;31:322-325.

74. Parihar MS, Hemnani T. Phenolic antioxidants attenuate hippocampal neuronal cell damage against kainic acid induced excitotoxicity. J Biosci. 2003;28:121-128. 